\title{
The Role of Religion in the Development of Communities: Comparison of Protestantism, TOKUGAWA AND ISLAM
}

\author{
Seyyed Mehdi Taheri \\ Faculty of Philosophy, Al-Mustafa International University, \\ Qom, I. R. Iran
}

\begin{abstract}
Considering the role of religion in different aspects of human life, two viewpoints, one positive and the other negative, are widespread among scholars. The present paper has dealt with the former, the importance of religion in social life and its role in the development of communities. Some scholars of the former, including Max Weber, claimed that Protestant is the only school of progress for societies while undermining the efficiency of other religions. In addition to casting doubt on Weber's exclusive viewpoint, the present paper through implementing Tokugawa religion by Robert Bellah, one of Weber's students, intends to explain the efficiency of Islam in development of societies. Thus, given the comprehensiveness of Islam and noticing social aspects of it along with individual ones, the main purpose of the present paper is to determine whether development and improvement have been taken into account by Islam or not. Despite Islam's consideration on this issue, the question is why Muslim communities are not as much developed as Western communities.
\end{abstract}

Keywords: Religion, Development, Protestantism, Tokugawa, Islam

\section{Statement of the Problem}

Regarding the role of religion in human social life, there are two general views among western scholars. Some scholars, such as Karl Marx, believe that 
religion plays no role in human social life and it is even considered as "the opium of the masses" (Motahari 2001: 3, 175). Conversely, other scholars, such as Max Weber, emphasize the role of religion in public life and believe that religious values can lead to the development of Western societies.

Weber believes that his model of the development of Western thought is universal and it undermines the efficiency of other religions, while it is necessary to develop the model of each society based on the religious and civilized principles of that society. On the same basis, Robert Bellah, one of the students of Weber school, has undermined the Weber's monopoly by paying special attention to the role of Tokugawa religion in the development of Japan.

Due to comprehensiveness of Islam and noticing social aspects of religion along with individual aspects, the main purpose of the paper is whether development and improvement have been taken into account in Islam or not. In spite of Islam's consideration on this issue, the question is why Islamic societies have not achieved growth and development as much as the Western societies.

\section{Definition of Progress and Development}

The concept of progress or development is a complex and multidimensional one and according to the theories of relativity and diversity of the various schools, different definitions have been provided for this concept, which are as follows:

Friedman: "A creative and innovative process for fundamental changes in the social system" (Gharabaghiyan 1990: I/7).

Multidimensional process that requires fundamental changes in the social structure, attitudes of the public and national institutions, as well as accelerating economic growth, reducing inequalities and eradicating absolute poverty (Todaro 1999: 136).

Social process in which the action is based on rationality and the society moves from unfavourable irrational logic towards favourable rational one (Jahanian 1998: 111). Considering the differences in the definition of the concept of development, it can be said that, in the broadest sense, this concept refers to a process in which all aspects of personal and social life of man is under development and change; changes that lead to the promotion of relationships with other people and with nature in the way of fundamental beliefs and attitudes. 


\section{The Role of Religion in the Development of the Societies}

\section{A. The Negative View}

Karl Marx, as one of the major thinkers in this group, believes that religion arises from fear and anxiety, and introduces it as an elastic-hallucinatory matter; but because of the pervasive role of religious belief, he, inevitably, finds a false term named "class ideology" for revolution and the change of the existing social order (Farasatkhah 1998: 137).

From Marx's view, religion is essentially the product of a class society. In this society, ideas, thoughts and other cultural phenomena such as language, religion, law, etc., as superstructures, arise under the influence of infrastructures that form the nature of economic relations of society. It means that only economic relations and production system are original and cultural phenomena are functions of this relation and production (Sanei 1993: 59). Ideology and social functions in Marx's model were defined only from the perspective of the dominant class and it just means giving legitimacy to the positions and interests of the dominant class over other classes which is in the form of the opium of the masses and leads to a sense of alienation and disintegration of revolutionary energy. So, on the basis of this definition, ideology is a form of false consciousness which aims to protect and preserve the dominant class (see: Roche 1989: 86-87).

In this regard, Marx, with the revolutionary performance, the realization of the hopes of the hereafter in the world, tried to disband religion (Eliade 1998: 336). Therefore, he believed that "the abolition of religion as an illusion and false happiness is necessary for the true happiness of people." (Scott \& Hall 2006: 26)

\section{B. The Positive View}

Regarding the belief of Max Weber to the direct relationship of economic system and ethics, he sought to find a supplementary for theories of Marx in order to dispose the illusion related to his revolutionary theory.

\section{Development of Protestant Religion in Western Societies}

\section{A. Weber and the Protestant Ethic}

The Protestant movement, started with Martin Luther's ideas, relies on the theory that man was created to serve God and to sanctify His greatness 
and man, through his rational and constant behaviour in job and task, can obtain the consent of God and become prosperous. Since self-discipline and piety are prerequisites for serving God, effort and work, temperance and moderation, dignity and awareness are integral conditions of self-discipline (Musai 1995: 418).

According to Max Weber, some religious teachings and precepts in religions tended to blame material and worldly gains, but after the birth of the Protestant movement, they stopped this blaming. Although Protestant beliefs and ethics became weak related to economic activities and pious life, habits and principles based on this belief lasted for many years (Hariri 1999: 50).

After a close analysis of contemporary culture, Weber concluded that the West, only through pious Protestantism, can transfer rational piety to the ordinary life of people, and this is the only thought that coordinates the worldly professional ethics on a regular basis to ensure the rescue of people; because the moral values of this religion along with work, effort and saving combined with religious duty, the foundations of capitalism collapsed in Europe (Hamilton 2002: 258).

\section{Reasons for the Progress of Protestant Religion}

Protestant reformers in their religious teachings focus on factors from which the elements of progress can be drawn:

- Profession is one of the most important forms of serving God and all honourable professions are as sacred as the pastors' jobs; not human obligation to be a punishment for the sin of the first human;

- Fatalism and the belief in magic are blamed and instead of routine life, a systematic plan of life should be designed;

- Denying extravagant lust and expanding capital accumulation (Musai 1995: 418).

The results of such elements were that believers of this religion turned to trying more, acting rationally and applying thrift and also indirectly engaging in the promotion of science and technology. They insisted that people should be able to read Bible in order to reach the Word of God without a mediator. Although early development of literacy had a religious motive, its long-range effects were non-religious. Gradually it became clear that by increasing the number of literate people, the spirit of initiative and creativity is blown in 
people and groups that are encouraged to literacy earlier take precedence of rival communities in the process of development (ibid.).

Due to the importance of these elements, Protestant religion created three main reforms in Christianity:

1. Removing intermediaries between man and God and the result is the value of the human personality;

2. Accepting the right to privacy of reason in religion;

3. Regarding livelihood, effort and work.

On the three elements of Protestants, Motahari believes that these principles are taken directly from Islam and they are the result of the crusades, the contact of the East and West in these wars and familiarity of Christians with Islamic values (Motahari 2001, XXI/463).

Considering the analysis on the successes of Western societies, Weber believes that Protestant religion by changing the criterion of "winners" and "steadfast", giving a justification for a new interpretation of "fate", putting emphasis on individual responsibility and authority, and insisting on the need for "hard work and penance" gives way to widespread social and economic system of capitalism in the West (see: Lashei 1975: 34).

In this regard, Weber believes that the most important concept in reforming the process of Protestantism is the concept of "professionalism" and a sense of responsibility at work which religious believers have crystallized in practice and caused the development and creation of new fields. This concept includes:

1. Work as a duty and a moral purpose;

2. No conflict between piety and accumulation of wealth;

3. Adopting the spirit and attitude of moral righteousness which leads to punctuality, diligence and thrift;

4. Earning more without considering the fleeting pleasures of life, avoiding the spirit of fun (Weber 1995: 66-67);

5. Hardworking, calculating, courageous and self-restrained people are reliable individuals who are committed to working, to the principles and ideas that are quite bourgeois (ibid.: 111-112).

Realization of this situation continued till the evaluation of religion in a regular secular task was considered as an excellent tool for piety, the safest way to prove the rebirth and the true faith and also a powerful instrument in order to expand static position towards life. Weber calls this status the "spirit of capitalism" (ibid.: 148). 
The results of the spirit of capitalism in Western societies from his perspective are as follows:

1. Legality of wealth accumulation as providence and religious duty;

2. Moral justification for the division of labour;

3. Attention to work as duty and ensuring the acquisition by grace;

4. Considering duty of the employer for the job;

5. The importance of piety, capital accumulation and productivity through compulsory piety as a result of practical thinking.

Conclusion: the idea of rational behaviour leads to innovation, social responsibility and economic development of the West and this situation just exists in the European-American environment where worldly piety leads to development. (ibid.: 140-155)

\section{Undermining the Role of Other Religions by Weber}

By defending rationality of Protestant Calvinism, Weber considers Western capitalism as a unique phenomenon and thus tries to evaluate the economic potential of moral value in some moral systems in order to specify that religious morality cannot lead to development.

Weber, on "primitive societies", believed that though tribal religion is somewhat rational, a religion focusing on global financial interests such as health, happiness and the rainfall can be considered as a magic, sacred and flexible; this form of religion is like a unitary force which unites family members of a group or large tribes.

Weber, on the discussion of "Religions of India", believes that Indian social-ritual practices are generally based on magical beliefs (Weber 2008: 458-482) and Brahmans, as a heredity social class and famous elites, emphasized the importance of rituals and sacred texts. They were rich and intelligent officials who were close to the centre of political power. They avoided revelry and luxury and at the same time pretended religious and pious rituals of the lower classes. So, a dual power has been formed in the Indian community which has led to continuing conflicts between social class priests and secular rulers in the history of India (Maurice 2000: 34).

In the case of religious morality of "Confucius", Weber knows that it is out of this world, follows peace in nature and lacks any doctrine of salvation. $\mathrm{He}$ also believes that although this religion acts as a cult of the Empire (as political ruler and priest), it has never created any powerful spiritual status and any degree of political autonomy for the leaders of this religion; because 
they did not engage themselves in economic activities and focused on the piety of children, literature, ethics, education and certain forms of rationality in order to maintain the position of God, establish social order and keep the internal balance of man through a guiding human behaviour; these were considered as obstacles to the development of the spirit of rational capitalism. In addition, at the local level, there were ancient rituals and folkish religions based on Taoian Sufi and different forms of religions and magical beliefs that due to the popular and irrational characteristics are more traditional than Confucianism (Weber 2008: 483-520).

In the "ancient religion of the Jews", the world is not eternal and unchangeable, but rather an occurred one and the current structure of the universe is the product of human activities and their response to God. Thus, the world is the product of the history designed to provide another way for the determined order by God. This religion lacks a distinctive sign of worldly piety. In other words, a person's relationship with the world in terms of the need to be saved is a relationship that involves the need to control the world (Bendix 2009: 223-275).

About the religion of Islam, Weber claims that this religion changed to the religion of fighters who led it to military ethics. Along with the development of Sufism in the style of mendacity, with extremist elements, it only served to emphasize moral traditionalists and was quite different from the systematic control of rational lifestyle; as a result, Islam did not have proportional ethics of rational capitalism in itself (Weber 2008: 305). In addition to the affairs of Muslims including women, objects of luxury and wealth, Islam accepts an absolutely pleasing nature and no austerity towards rationality and development is apparent in it (Weber 1965: 263-264).

The most important factor for the lack of development in Islamic societies is the hereditary governmental ruling in the political and economic structure of the government and the lack of independent establishments in the society. In such a condition, development in the financial and political structures was dependent on successful seizure of new lands and the use of them to keep the central government. Moreover, by improving martial forces, the court was trying to protect its monopoly power with acts such as limiting the development of establishments and independent groups in a hereditary society.

\section{A Review on Weber's Viewpoint}

The variety in expressing theories about development by different theoreticians shows that these people propose a theory according to the needs of the society to change the status quo and achieve an ideal condition. Hence, 
the development of every society should be in line with social and cultural needs of that society, and a society can benefit from the development pattern of other societies only if they have social and environmental commonalities with those societies. However, without having common religious, social, and environmental factors, such pattern adoption won't lead to development.

Despite the aforementioned fact, with using the Western experiences most Western theoreticians, Max Weber being one, have investigated other societies and analyzed non-Western societies with their pattern and theories and with prejudice towards special values have sought to establish their ubiquitous pattern in the depth of non-Western societies. In this regard, Wolfgang Sachs (1998) holds that "The issue of development is based on the Western epistemology that, based on it, nations should follow the path of Western counties".

Like evolutionists in science, Weber considers all societies with one entity and attributes the same rules to all of them. He regards all signs of religion and practice of religion the same and does not differentiate between primitive religions and prophetic and Abrahamic religions. With a view belonging to Protestant teachings, he investigated other religions and, hence, did not find any remarkable teaching in line with the words of the Protestant sect. Exactly like Marx, who viewed Christianity as it was practiced in the church then and expressed his incorrect judgment against the religion, Weber also attributed the act of Muslims and Islamic rulers to Islam due to his imprecise investigation of Islam, while issuing an absolute judgment about Islam and its attitude towards development needs an exact recognition.

Weber's analysis of Islamic teachings is in line with Western views and is completely materialistic and holds that humans focus all of their efforts only on living and livelihood in this world and ignore the Hereafter. The differing aspect of Islam with Protestant is their attitude towards the Hereafter. In Islam, living in this world is like a plantation for the Hereafter, and in the view of Islam, development is a tool for ethical development and elevation, humanistic attainments, and freedom of human concerns. Accordingly, in the Islamic thought, advantageous motivations and maximizing materialistic joys is not the main goal for the endeavour of human per se. However, by accepting benefit gaining and materialistic joy through legitimate ways, Islam considers the human a pivot of development and puts materialistic-spiritual development as a goal. Nonetheless, for the development in Western societies, only materialistic aspects are observed as an evaluation index and no attention is paid to spiritual aspects and moral-spiritual needs.

At last, Weber's analysis of Islam as a cast religion (martial and landholding casts) is incomplete. Although Islam has had many defensive and offensive wars, it has provided a complete order for controlling all aspects of human life and has words in different fields which we will discuss in the last section. 


\section{The Role of Tokugawa Teachings in the Development of Japan}

\section{Tokugawa Empire}

Ieyasu was the founder of Tokugawa Empire. Tokugawa Empire was established in Tokyo in 1603, and Japan started a long-term peaceful time which is considered as the beginning of the new era for Japan. During the period from 1603 to 1667 called Tokugawa Era, Japan took a seclusion national policy and closed its borders to foreigners (Faridnezhad 2006: 24)

A centralized political system was formed in the seclusion era and with uniting powerful feudalists who each had control of an area of Japan. In addition, the Tokugawa dynasty used the holy position of the emperor to decrease emperor's control of the country to the least possible extent. This almost centralized system resulted from the execution of three main policies:

1. The execution of seclusion policy and the forbiddance of any cultural relations with other countries except China;

2. Assuring the obedience of great feudalists through the kidnapping system; while they travelled a lot to handle affaires in their sovereign area, their spouses and children used to stay in the capital;

3. With a cast-like hierarchical system, on the one hand, loyalty and obedience of lower ranking classes were guaranteed and, on the other hand, each class had its own special merits and status. Based on this hierarchical system, the Tokugawa government established for common people exact rules like the Samurai cast did concerning their accommodation, clothes type, and social background.

\section{The Effect of Religion on the Development of Japan in the View of Robert Bellah}

Robert Bellah was a sociologist who was influenced by Weber's ideas and who based his analyses on them. By investigating economic development factors of Japan (as a non-Western country) under the influences of traditional, religious, and ethical foundations, he sought to determine different aspects of intellectuality in economic and social foundations to see the role of Tokugawa religion in the quick and unique economic development of Japan.

In his investigation, he observed religion as "those attitudes and practices of a person formed and done in the light of ultimate values". Therefore, when great religions of the world rose after primitive or magical ones, motivation was provided to redefine the pivotal values of a society from traditionalism to intellectuality. Accordingly, he tried to study those features of Japanese 
religions which probably caused such an important change in the pivotal values of the society (So 2007: 60).

According to this study, Japanese religion formed a true value system in the society, and this religion in the history, brought in Samurais' behavioural system and ethics. However, later under the influence of Confucianism and Buddhism, this religion spread so much that it became the religion for the whole Japan (ibid.: 61-62).

By investigating rules and ethical system of Japanese Samurais class, he concluded that ascetic life, knowledge appreciation, learning and diligence, providence and extravagance avoidance, commitment, etc. affected not only the ethical rules of Samurai, but also the whole ethical and value system in many parts of Japanese society. Samurai class also took control of economic and business activities of Japan and in the revival time of empire (1868-1912), an era when the basis of changes and economic development of Japan was established, Japanese leader followed ethical and spiritual system of Samurai (Hariri 1999: 51).

\section{Development Elements in Tokugawa Religion}

Among Tokugawa teachings that have development elements are the ones that include ethical requirements with the following features:

1. Changing diligence and endeavour in this world especially in the professional field of everybody as the best ethical duty;

2. Forming an attitude based on piety and ascetic life related to consumption induced from the stories and instances;

3. Always being hopeful for the mercy of God;

4. In the happiness of mornings and the pleasure of evenings, not being ignorant of activation and endeavour;

5. Trying hard in your family profession;

6. Abstaining from your wishes for any luxury without benefit;

7. Refraining from gambling;

8. Not being greedy and being satisfied with little;

Although gaining profits through illegal ways is prohibited, according to the teachings of "Bodhisattva" reasonable profit for working is religiously regarded legitimate. Professions of business people and craftsmen are legitimate as they hold these activities for the benefit of consumers (Bellah 1957: 120). Also, by being lucrative for other members of society, business people and craftsmen were entitled to gain profit for them, and this was virtue and eminence of order (Jiri-rita). To show the influence of religion on the acts and 
conduct of Japanese business people, Bellah supports his idea by referring to the accumulation of Shin temples in the commercial cities "Omi", the big number of business people in temples and mentioning their good deeds which are narrated in the biography of these people (So 2008: 63).

The result of Bellah's investigations about Tokugawa religion shows both direct and indirect impacts of religion on the quick development of economics in Japan.

For the direct influence, he investigates the "Shinahu" sect. For this sect, having a sheer belief in achieving salvation was enough and, hence, it was possible for everybody, even the most wicked ones, to be forgiven. Nonetheless, up to the middle of Tokugawa time, due to the preaching and teachings of Rennyo Shonin, the second founder of the sect, salvation and moral deeds had an unbreakable connection, and there was no word anymore about wicked people reaching salvation. So, by changing religious values, an act based on morality was also emphasized as a sign of salvation (Eyvazi 2005: 34).

The indirect influences were also achieved through the political system and the family. In the arena of political system, the principle of obedience derived from Japanese Confucianism was realized in the ethics and economic methods of Japanese Samurais. A samurai did his professional duties with greatest devotion and without any expectations in the form of fulfilling unlimited liabilities. According to Bellah, this professional ethics spread through the rest of the society in the Tokugawa time, and it was expected that city dwellers also be loyal to their lords and serve them or serve for the salvation of their country. (So 2008: 63-64).

For the family, he also holds that the idea of "unlimited duty" was used not only for managing the whole country, but also for managing commercial institutes. These institutes expected gratefulness from all their members as parents expect it from their children. In addition, high valued standards for duties were arranged for the commercial institutes, so acts such as laziness, extravagance, and indecent behaviours were disdained, and damaging the reputation of the commercial institutes or stagnating the works led to the embarrassment of the family and ancestors. Therefore, economic motivation of Japanese business people was based on a kind of "family interests", not a personal gain seeking. These family rituals and duties were enhancing integrity, equality, and trust and developing the common rules of working, and they, in practice, created a powerful propelling force to achieve an economic intellectuality in Japan (ibid.: 65). 


\section{Islamic View of Development}

In the Islamic viewpoint of development process, two basic functions are considered; the personal function considering the relationship between human and God and the social function considering the presence of religion in the society for moving the society towards the desired perfection. In this regard, principles and values set as the base in the society are as follows:

1. Gaining wealth, profit, and setting mundane goals as absolute aims is wrong;

2. This world and gaining possessions is a tool for spiritual perfection of humans;

3. To achieve a desirable Hereafter, you have to go through this world, and anyone who does not have this world will not have the Hereafter;

4. The falsehood of deserting this world and monasticism for the sake of the Hereafter;

5. Accepting the inherent tendencies and interests of humans for the affairs of this world, if they are not against the main goals;

6. Maximum use of this world for achieving perfection;

7. Undesirability of financial poverty in the view of Islam;

8. The relation of this world and the Hereafter is of followed and follower type, and anyone whose goal is the Hereafter would also have this world;

9. The world Islam introduces has no disagreement with development (Musai 1995: 365-366).

Gain seeking motivations and maximizing mundane joys are not regarded as the ultimate goal of human endeavour per se. By accepting to gain profits and mundane joys through logical and reasonable ways, and presenting different indexes, Islam has paved the way for development which we will discuss later.

\section{Development Indexes in Islam}

A part of Islamic teachings in which development indexes can be observed vividly are as follows:

\section{Seeking Knowledge}

The holy Quran in many verses invites people to think logically and reasonably and introduces literacy as an obligation for all humans whether they 
be a man or a woman. The holy prophet of Islam says: "Seeking knowledge is an obligation on every Muslim man and woman" (Nouri 1987: XVII/249).

\section{Considering Development and Cultivation}

A human as caliph and the representative of God on the earth is obliged to develop on the earth: "It is He who hath produced you from the earth and settled you therein." (Quran 11: 61)

\section{Doing Jobs as Worshipping and a Religious Duty}

Doing jobs, endeavour and seeking pure livelihood everywhere and any time is considered a valuable kind of worship. Prophet Muhammad says: "Seeking pure livelihood is an obligation on every Muslim man and woman." (Majlesi 1982: IX/103)

Imam Reza also says: "By working, anyone who seeks divine bounteousness to meet his family needs will be rewarded as someone who fights on the way of God." (Kulaini 1986: V/88)

Working in this world has an otherworldly nature and is considered for the otherworldly salvation, and this is a unique merit of Islam. In this regard, Allamah Jafari says: "No school of thought and no thinker can express the great value Islam has attributed to working." (Jafari 2000: 58)

\section{The Suggestion of Thanking for the Boons of God}

"And gave you Good things for sustenance: that ye might be grateful." (Quran 8:26)

Using the boons of this world that God has provided humans with: "But seek, with the (wealth) which God has bestowed on thee, the Home of the Hereafter, nor forget thy portion in this world." (28:77)

\section{Forbiddance of Deserting this World for the Sake of Religion or} Setting Aside the Religion Due to the World

In the Islamic viewpoint both of these conditions are forbidden, and in this regard Imam Sadiq says in a narration: "He is not from us who deserts this world due to his religion or deserts his religion due to this world." (Majlisi 1982: LXXVIII/321) 


\section{Trying to Spend Less and Limiting Extravagancy}

"Eat and drink but do not extravagate because Allah does not like extravagant people." (7:31)

\section{An Emphasis on Observing Order to that Extent that Regards it Next to the Divine Piety}

In this regard, Imam Ali says: "I suggest you to have divine piety and order in your deeds.” (Razi 2002: 47)

\section{Reproving Poverty}

Islam has reproved poverty as a harmful phenomenon and has always asked people to seek removal of poverty from the Islamic society. Accordingly, Imam Ali calls poverty the major death, and says it defects the Faith, wonders the reason, and is a cause of enmity. Moreover, in Imam Ali's opinion, poverty is such a kind of disaster which, if it affects some parts of the society, will block the growth and flourishing path (ibid.: 63, 388).

Besides some prayers that have been about removal of poverty, some financial programs like Spoils, the Fifth, and Alms Tax have been set by Islam. These are clear proofs of Islam's anti-poverty attitude, in which the Islamic government and people have the responsibility to fight against poverty. It should be noted that the cases which have reproved richness relate to a kind of richness that leads to negative results such as insurgency against and shunning from God.

\section{Social Justice}

Islam has emphasized social justice as a principle. Noting this principle is so important in the Islamic thought that establishment of justice has been enumerated as a goal for the prophets' appointment (ibid.: 25).

Muhammad Baqir Sadr the Martyr considers three necessary elements for the fulfilment of social justice: the bail principle (i.e. a Muslim's responsibility to satisfy others' vital and urgent needs and the necessity of planning by the Islamic government); the Iqalah principle (i.e. the Islamic government's responsibility to pay the necessary expenses of unable people and to provide them with necessities of life); and keeping the balance (using different means like tax) (Larijani 1998: 367). 


\section{Observing Moderateness}

Observing moderateness based on apt planning of material life is among the necessary issues in Islam (Majlisi 1982, LXXVIII/327).

Since a great deal of discussions and books (Abwab) of jurisprudence like business, transactions, renting, mortgage, lending, judgment, ordained punishments, the Fifth, the Alms Tax, deposit, and Jihad are related to everyday life and mundane affairs, then one can claim that Islam has presented the growth and development elements well. Here, the question might arise that although Islam has a rich, dynamic, and initiative culture, why are most of Islamic countries among the underdeveloped countries?

\section{The Main Reasons for Underdevelopment of Islamic Countries}

In order to find the answer to this question, it is necessary to provide a brief history of Islamic countries. The rise of Islam occurred in a country which was among the most underdeveloped parts of the world regarding culture and civilization, to the extent that the era was called "Ignorance era". The growth of the area during the prophethood of the Islam's prophet is obvious in that the people moved from idolatry and savagery to monotheism, civilization, law-obedience, and order.

Until the $12^{\text {th }}$ century, exceptional scholars produced knowledge in fields like medicine, astronomy, chemistry, mathematics, art, architecture, etc. and provided the humanity with outstanding scientific achievements. During this era, Europe and West did not have any considerable growth and scientific production, but rather, Europe was drowned in savagery, autocracy, and exploitation, and some parts of Europe were under Muslim's control. Moreover, the period extending from the $14^{\text {th }}$ to the $17^{\text {th }}$ century was called "the golden era of Islam" (Ranan 1992: 281), and Western scholars consider it the pinnacle of Islamic culture and civilization. They confess that at the time when Europe and West were obsessed with medieval thoughts, Islamic world and Iran enjoyed brightest civilizations (Durant 1995: VII/624).

Therefore, it seems necessary to discuss the main reasons of the present-day underdevelopment of the Islamic world.

Not observing Islamic orders after the Noble Prophet's demise: soon after the Prophet, caliphate fell to some who were unaware of Islam's spirit; their intention was power and principalship, not practical devotion to the orders of Islam and Quran. Therefore, the true Islam was marginalized and its developed rules were never observed. Although different governments 
were established in the name of Islam, they did not properly execute Islamic rules in the newly conquered lands (El-Zein 1977: 41-60).

Distancing from the true Islam: Islamic culture and civilization were indebted to true teachings rooted in the Quranic verses and traditions. However, the true teachings of Islam changed with the pass of time. For example, "fate" was considered concomitant with "predetermination", "religious dissimulation" was deviated to "acceptance of tyranny", and "awaiting" was turned into "toleration of different injustices". In the same way, "believing in the other world" was interpreted as "depriving from worldly life", and "patient endurance" was assumed as "reclusion". However, they brought new excuses to justify their deeds (Kashefi 2008: 206).

Preferring personal interest over Islam's interests: unfortunately, Muslims and Islamic rulers have preferred their personal or group interest and intentions over Islam's interest in application of Islamic rules, and have tried to collect money, obtain or keep high positions, and ignore the society and Islamic government's interests. Therefore, one should not attribute the negative preference of Islamic government rules and Muslims to Islam.

Internal wars within the Islamic world territory and destruction of Islamic countries: attacks like those Mongols and ears of Umayads and Abbasids, etc. absorbed the energy and talents of the Islamic world and ruined the society's security as the most important element of development. Nonetheless, some knowledge production that happened in some parts of the Islamic world came into existence due to the peace, convenience, and security that was caused by personal efforts of outstanding scholars and minor support by the governments (Alamdari 2002: I/296).

Dominance of colonizers over Islamic countries: the downfall of big Islamic caliphates paved the way for arrival of colonizers into the Islamic countries. Colonizers plundered their wealth and weakened their culture. Besides, colonizers imposed their consumption culture on the Islamic countries.

Dominance of autocracy in the Islamic countries: autocracy blocked the development in two ways: first, dictators tried to gain personal power. Moreover, they tried to satisfy the interest of colonizers in political, economic, and cultural domains.

Following Western models to attain development: the "Westernization of the world" dialogue considers that all nations should follow the path and model of the Western counties to develop. However, for development, different countries should prepare a native model based on their own conditions and facilities, national and international capacities, ideological beliefs and Islamic values, cultural difference based on identity, and ethical and spiritual values prevalent in their own societies, so as to lead the social system toward a better life based on the capabilities of that certain society. 


\section{Conclusion}

There are two main perspectives regarding the role of religion in human social life: for some thinkers such as Karl Marx, ideology and social functions just supply the interests of the dominant class and justify their domination over other classes, and religion, as the opium of the masses, causes the alienation and the collapse of the revolutionary energy of the other classes. On these grounds, real happiness is sought for people through abolishing religion as an illusion and false happiness.

The second group emphasizes the role of religion in public. One of them is Max Weber who believes that ideologies and social phenomena, in addition to correlation with other social factors, may lead to social changes including the change in the productive system. He believes that the modern world is based on rationality, calculation and prediction and with the advent of religions based on books, this rationality and systematicity has flourished in religions and this condition has reached the peak in the Protestant ethic. Religious beliefs stemming from Calvinism have had a major impact on social innovation and economic development and rational piety in Western Europe and the United States and it has led to the development of these societies.

Defending the rationality of Calvinism in Protestantism, Weber believes that Western capitalism is a unique phenomenon. Besides, by comparing religions, he aims to show that the reason for the prevention of the development of rational economic thinking in Eastern countries is the result of the way that Eastern religions act on the basis of it. However, the criterion of rationality in Protestantism is different from other religions, such as Islam.

Robert Bellah, one of the students of Weber school, violated Weber's monopoly by studying the economic development of Japan as a non-Western country influenced by its traditional, religious and moral native institutions.

In this regard, we claim that Islam is the perfect religion as divine which considers all personal and social aspects of life and Islamic culture with emphasis on elements such as efforts to acquire knowledge, subsistence and enjoyment of worldly blessings, hard work, discipline, elimination of poverty, prevention of waste, social justice, etc. which pave the way for an appropriate path of development.

Although some verses and traditions give rise to the development of society, there are some important reasons for the lack of progress in Islamic countries including: lack of practice of Islam after the Prophet Muhammad, deviation from original Islam, preferring your own interests over the interests of Islam, existence of civil war in the territory of the Islamic world and destructive military attacks on Islamic countries, colonial oppression of Muslim countries and following the Western models to achieve progress. 
To compensate for the backwardness of Islamic countries in the current situation, it is necessary to benefit from the experience of developed communities in the development process in order to provide an idealized vision of society developed in a cultural, national, religious and native framework. This way leads us to the emancipation of society from backwardness towards an ideal Islamic society and also helps us not to face social, theological and ethical problems of the West.

Received: December $14^{\text {th }}, 2015$.

Accepted: March 28 $8^{\text {th }}, 2016$.

\section{References:}

The Holy Quran.

Alamdari, Kazem (2002), Reason for Backwardness of Iran and Development of the West, Tehran, Toseeh Publication.

Bellah, Robert (1957), Tokogawa Religion: The Cultural Roots of Modem Japan, New York, Free Press.

Bendix, Reinhard (2009), Mental Image of Weber, translated by Mahmoud Rambod, Tehran, Hermes Publication.

Durant, Will (1995), The Story of Civilization, Tehran, Elmi Farhangi Publication.

Eliadeh, Mircea (1998), Religious Studies, translated by Khoramshahi Bahaoddin, Tehran, Elmi-Farhangi publications.

El-zein, Atef Samih (1977), Roots of Weakness and Backwardness of the Muslims, translated by Mohammad Taghi Kamal Mahmoud Rajabinia, Qom, Hejrat publications.

Eyvazi, Mohammad Rahim (2005), "The role of religion in the development of scientific culture”, Qabasat 9 (2): 19-47.

Farasatkhah, Maghsood (1998), Religion and Society, Tehran, Sherkat sahami Publication.

Faridnezhad, Shervin (2006), "Japanese wooden Basmhhay in the seventeenth and eighteenth centuries", Journal of Art and Culture 6 (4): 72-77.

Gharabaghiyan, Morteza (1990), Economic Development, Tehran, Nei Publication. Hamilton, Malcolm (2002), Sociology of Religion, translated by Mohsen Salasi, Tehran, Tebyan.

Hariri Akbari, Mohammad (1999), Development Management, Tehran, Qatreh Publication.

Jafari, Mohammad Taghi (2000), Work and Wealth from the view of Islam, Tehran, Payame Azadi Publication.

Jahanian, Nasser (1998), "The evolution of development and its relation to religion", Qabasat 2 (3): 109-119.

Kashefi, Mohammad Reza (2008), History of Islamic culture and civilization, Qom, Almustafa International University Publication. 
Kulaini, Muhammad ibn Yaqoob (1986), Al-Kafi, Tehran, Dar al-maktab Library.

Larijani, Mohammad Javad (1998), Religion, Governance and Development, Tehran, Moasser Publication.

Lashei, Hossein (1975), Review and critique of religious sociology, Emile Durkheim, Max Weber and Karl Marx, Tehran University, Faculty of Social Sciences.

Majlisi, Muhammad Baghir (1982), Bihar al-anwar, Beirut, Daru Ihya Al-turas al-Arabi.

Maurice, Bryan (2000), "From the perspective of Max Weber's sociology of religion", translated by Mohammad Fuladi \& Seyyed Hossein Sharaf al-Din, Marefat 9 (2): 29-44.

Motahari, Morteza (2001), Collected Works, Tehran, Sadra publication.

Musai, Meysam (1995), Religion and Development Culture, Tehran, Islamic Propagation Organization.

Nouri, Hossein (1987), Al-Vasail, Qom, Institute Ahl al-bayt.

Ranan, Collin (1992), History of Science, translated by Hassan Afshar, Tehran, Markazi Pubication.

Razi, Seyyed (2002), Nahj al-balagha, translated by Mohammad Dashti, Qom, Parsayan.

Roche, Guy (1989), Social Change, translated by Mansoor Vosughi, Tehran, Nei Publication.

Sachs, Wolfang (1998), A new Look at the Concept Development, translated by Vahid Bozorgi and Farideh Farhi, Tehran, Markazi Publication.

Sanei, Parviz (1993), Sociological Values, Tehran, Ganje Danesh Library.

Scott, Jolie \& Hall, Irene (2006), The Sociology of Religion, translated by Afsaneh Najarian, Tehran, Rasesh publication.

So, Alvin Y. (2007), Social Change and Development, translated by Mahmoud Habibi Mazaheri, Tehran, Institute for Strategic Studies.

Todaro, Michael (1999), The Economic Development in the Third World, translated by Gholam Ali Farjadi, Tehran, Institute of Research and Planning.

Weber, Max (1965), The Sociology of Relegion, translated by Ephriam Fishoff, London, Beacon Press.

Weber, Max (2008), The Community of Faith, translated by Ahmad Tadayon, Tehran, Hermes Publication.

Weber, Max (1995), Economy and Society, translated by Abbas Manoochehri, Tehran, Moli Publication. 